\title{
Effects of Selected Seed Treatment on Germination Rates of Five Range Plants
}

\author{
LARRYE C. WEAVER AND GILBERT L. JORDAN
}

\section{Abstract}

Effects of various treatments on germination rates were determined for Lehmann lovegrass (Eragrostis lehmanniana Nees), 'Cochise' lovegrass (Eragrostis lehmanniana Nees $\times$ Eragrostis tricophora Coss \& Dur), Boer lovegrass (Eragrostis curvula var. conferta Nees), blue panicgrass (Panicum antidotale Retz.) and four-wing saltbush (Atriplex canescens (Pursh) Nutt.) seeds. Rates were approximations of time to $50 \%$ germination, and seed treatments included applications of potassium nitrate, ammonium nitrate, gibberellic acid, and heat desiccation. Germination rates could be increased, but treatment effects were not uniform between seed lots within a species or among species. Desiccation at $70^{\circ} \mathrm{C}$ for 24 hours was particularly effective in increasing germination rates of Boer and Lehmann lovegrass seeds. Increased rates of germination of certain species might aid in establishment of range seedings made under limited moisture conditions of the Southwest.

A relatively high rate of germination is believed to be a key characteristic of various plants adapted for seeding semiarid environments, promoting germination during ephemeral moisture periods (Jordan 1981). Germination rates have not been relevant or of major concern in most germination research and generally not considered as a measure of seed quality for semiarid seedings. Conscquently, quantitative data are scarce, and standard procedures do not exist to characterize germination rates among species, seed treatments, or to compare among reports in the literature.

Germination rates of a seed can be changed due to temperature and daylength environments of the parent plant (Gutterman 1972, Koller 1972, and Harrington 1972). Gibberellic acid (GA) has been found to increase rates of germination (Hartmann and Kester 1968). No plant contains all of the 37 known gibberellins (Lang 1970), but all plants contain at least one of them (Sosebee 1977). Hence, the exogenous application of different gibberellins often results in different responses of individual species. Ammonium and potassium nitrates are often inhibitory to the germination process except in low concentrations where they have been found to promote germination of many species (Koller 1972), Macguire 1972, Hartmann and Kester 1968). Effects of nitrates on germination rates have not been reported. Germination characteristics, including rates, of many species have been changed by heat desiccation at temperatures ranging from 60 to $80 \mathrm{C}$ (Koller 1972, Haferkamp and Jordan 1977, Maun 1977, and Stone and Juhren 1951).

A better understanding of germination rates may clarify some of the variable reponses observed in range seedings. A study was conducted to (1) determine germination rates of 5 species commonly used for revegetation of semiarid rangelands in Arizona and (2) determine if selected seed treatments could change germination rates sufficiently to affect range seeding results.

The selected species were Lehmann lovegrass (Eragrostis lehmanniana Ness), 'Cochise'lovegrass (Eragrostis lehmanniana Nees $\times$ Eragrostis tricophora Coss \& Dur), Boer lovegrass (Eragrostis curvula var. conferta Nees), blue panicgrass (Panicum antidotale Retz.) and four-wing saltbush (Atriplex canescens (Pursh) Nutt.).

Authors are range specialist, Lesotho, Africa; and professor, range management, School of Renewable Natural Resources, University of Arizona, Tucson 85721

This paper is published with approval of the Director, Agricultural Experimental Station, College of Agriculture, University of Arizona as Journal Paper No. 3899.

Manuscript accepted October 28, 1984.

\section{Methods and Materials}

\section{Plant Materials}

The species selected had good drought tolerance and persistance but they differed widely in ease of establishment in range seedings in Arizona. All accessions used in this study had a high level of seed uniformity compared with most native range plants and were produced under uniform controlled cultural conditions. Seed lots selected were typical of seed used for range seedings. To evaluate possible variation within a species, 2 accessions and 2 seed lots of Lehmann lovegrass were used.

Seed was provided by the Soil Conservation Service, USDA Plant Materials Center in Tucson, Arizona. Accession A-130 of blue panicgrass was harvested as Lot 6060 in October 1978. Accession NM-155 of four-wing saltbush was harvested as Lot 6017 in April 1977. Lot 4934 of Accession A-84 of Boer lovegrass was harvested in October 1970, and 'Cochise' lovegrass was harvested as Lot 6200 in September 1980. Two Accessions, A-68 and L-19, of Lehmann lovegrass were studied. Accession A-68 was the commercially available seed utilized for seeding efforts in the Southwest. The 2 lots of A-68 were Lot 6092 harvested July 1979 having a germination of $54 \%$ and Lot 6101 harvested October 1979 having a germination of $96 \%$. Both lots werc harvested from the same field Accession L-19 was developed as a cold-tolerant variety but had not been released for commercial production. No Lot number was assigned to Accession L-19 but the date of harvest was 1967.

\section{Methods}

The large number of seeds involved required division of the study into two experiments. The first experiment studied the effects of gibberellic acid $\left(\mathrm{GA}_{3}\right)$, potassium nitrate $\left(\mathrm{KNO}_{3}\right)$, and ammonium nitrate $\left(\mathrm{HN}_{4} \mathrm{NO}_{3}\right)$ solutions on germination rates Gibberellic acid was applied in solution concentrations of 0.014 $0.14,1.4$ and 2.8 millimolar. Potassium and ammonium nitrates each were applied at concentrations of $0.02,0.04$, and 0.08 , and 0.16 molar. The second experiment involved desiccation of seeds with heat prior to germination. Disiccation was accomplished by drying seed at $70^{\circ} \mathrm{C}$ for 24 hours in a forced-draft oven.

Prior to germination, seeds were run through a seed blower to remove lower density seeds and trashy materials. Three 100 -seed samples (replications) were counted for each of the accessiontreatment combinations, and samples were stored in small vials until initiation of the experiment. All germination experiments were conducted in a Cleland Germinator at a constant temperature of $20^{\circ} \mathrm{C}$. Light was not controlled but was permitted to enter the plexiglass door of the germinator. Quality and intensity of light received in the germinator was not measured. Light source was from typical flourescent lighting of the laboratory and daylight through the laboratory windows.

Germination tests were conducted on Whatman No. 3 filter paper enclosed in 100 by $22 \mathrm{~mm}$ petri dishes. For all species, except four-wing saltbush, filter papers were initially wetted with $2.5 \mathrm{ml}$ of germination solutions of nitrates or GA. Four-wing saltbush seed (dewinged) required $3.5 \mathrm{ml}$ of solution for the initial wetting because of its larger size and greater absorption. The nitrate and GA solutions for the initial wetting of saltbush were proportion- 
ately more dilute to compensate for the larger volume required. Tap water in the same quantities was used for initial wetting and rewetting of the controls and heat-treated seed. Distilled water was used in making chemical solutions and for subsequent rewetting to maintain integrity of the solutions. The 100-seed samples were then sprinkled from storage vials on to surfaces of wet filter paper.

Germination counts were recorded at $24,36,48,60,72,84,96$, $108,120,144,168,192$, and 216 hours. Germinated seeds were removed from the petri dishes as they were counted. Germination was defined in this study as the point at which the radicle became visible, about $1 \mathrm{~mm}$ or more in length. Germination rates were determined according to the following equation: (Gulliver and Heydecker 1972).

where

$$
\mathrm{CRG}=\frac{\Sigma \mathrm{n}}{\Sigma(\mathrm{Hxn})} \times 100
$$

CRG = Cocfficicnt of Rate of Germination

$\mathrm{n}=$ The number of seeds germinating at hour $(\mathrm{H})$ of reading.

$\mathrm{H}=$ The number of the hour, counted from the hour of sowing.

The values obtained for CRG can be used to compare germination rates among species or changes in rate due to different treatments. The larger the CRG, the higher the rate of germination. The CRG is equivalent to the reciprocal of the Mean Time to Germination (MTG) in hours multiplied by 100 , an approximation of the time when $50 \%$ of germinable seeds have germinated. For brevity in this paper, rate will be used instead of CRG.

The experiments were set up in a completely randomized design. Analysis of variance was conducted to determine if significant differences existed within a species due to treatments. Least Significant Difference (LSD) tests were conducted at the 0.05 and 0.01 level of significance.

\section{Results and Discussion}

Mean germination rates for each accession and treatment are presented in Table 1. Germination profiles have been presented to illustrate relative, typical differences among species and treatments (Figs. 1, 2 and 3).
Lots 6101 and 6092 of A-68 Lehmann lovegrass showed wide differences in germination rates which were 1.71 and 1.39 for the controls, respectively. Rates for 6101 treated with $\mathrm{KNO}_{3}$ increased with $0.02 \mathrm{M}$ and decreased with $0.16 \mathrm{M}$. Rates for 6092 were decreased with $\mathrm{KNO}_{3}$ of $0.04 \mathrm{M}$ or greater. The difference in response between these two lots was believed due to their different seasons of harvest. Similarly with $\mathrm{NH}_{4} \mathrm{NO}_{3}$, rates of Lot 6101 were improved with concentrations from 0.02 to $0.08 \mathrm{M}$ but were depressed by $0.16 \mathrm{M}$. Lot 6092 was not affected by low concentrations, but rates were depressed by $0.08 \mathrm{M}$ or greater (Table 1).

Treatment with GA at concentrations up to $2.8 \mathrm{mM}$ increased germination rates of Lot 6101 . Lot 6092 was not affected by GA. Gutterman (1972) reported seeds produced under shorter day lengths have higher germination rates, which he correlated with higher GA concentrations in the seeds. The more responsive Lot 6101 was produced under shorter daylengths than Lot 6092

Heat desiccation caused highly significant $(P=0.01)$ increases in germination rates of Lots 6101 and 6092. Compared with the controls, the time to $50 \%$ germination occurred one day earlier (Fig. 1).

Germination rates of accession L-19 of Lehmann lovegrass were not affected by any treatments except for the depression of rates caused by 0.08 and $0.16 \mathrm{M} \mathrm{KNO}_{3}$ and $0.16 \mathrm{~m} \mathrm{NH}_{4} \mathrm{NO}_{3}$ (Table 1, Fig. 2). Although L-19 was closely related to accession A-68, it was distinctly different by it lack of response to heat desiccation.

'Cochise' lovegrass had the highest germination rate for the control of any accession in this study with an MTG of 42 hours (Fig. 2). No treatment improved rates but all nitrate concentrations and $\mathrm{GA}$ at $2.8 \mathrm{mM}$ severely depressed rates (Table 1).

The germination rate of the control for blue panicgrass, A-130 was not improved by any treatment. Concentrations of nitrates above $0.08 \mathrm{M}$ were slightly to strongly inhibitory to rates (Table 1, Fig. 2).

Boer lovegrass, A-84, was the slowest germinating accession in this study with a rate of 0.85 for the control, an MTG of 118 hours. Highly significant $(P=0.01)$ increases of rate were attained with heat-treated seed or GA solutions above $1.4 \mathrm{mM}$. Time of $50 \%$ germination was achieved 30 to 46 hours earlier. Nitrates were

Table 1. Effect of various seed treatments on germination rates of selected species. Data are the reciprocal of the time in hours to $50 \%$ germination, multiplied by 100.

\begin{tabular}{|c|c|c|c|c|c|c|c|}
\hline \multirow[b]{2}{*}{ Treatments } & \multicolumn{7}{|c|}{ Species } \\
\hline & $\begin{array}{l}\text { Erle } \\
6101\end{array}$ & $\begin{array}{c}\text { Erle } \\
6092\end{array}$ & $\begin{array}{l}\text { Erle } \\
\text { L-19 }\end{array}$ & $\begin{array}{c}\text { Erle } \\
\text { 'Cochise' }\end{array}$ & $\begin{array}{l}\text { Ercu } \\
\text { A-84 }\end{array}$ & $\begin{array}{c}\text { Paan } \\
\text { A-130 }\end{array}$ & $\begin{array}{c}\text { Atca } \\
\text { NM-155 }\end{array}$ \\
\hline Control & 1.71 & 1.39 & 1.47 & 2.37 & 0.85 & 1.13 & 1.05 \\
\hline $\begin{array}{l}\mathrm{GA} \\
0.014 \mathrm{mM} \\
0.14 \mathrm{mM} \\
1.4 \mathrm{mM} \\
2.8 \mathrm{mM}\end{array}$ & $\begin{array}{l}1.87^{*} \\
1.87^{*} \\
1.81 \\
1.87^{*}\end{array}$ & $\begin{array}{l}1.47 \\
1.41 \\
1.34 \\
1.36\end{array}$ & $\begin{array}{l}1.49 \\
1.52 \\
1.58 \\
1.58\end{array}$ & $\begin{array}{l}2.49 \\
2.41 \\
2.23 \\
2.17 * * \\
\end{array}$ & $\begin{array}{l}0.92 \\
0.94 \\
1.07^{* *} \\
1.13^{* *}\end{array}$ & $\begin{array}{l}1.17 \\
1.17 \\
1.10 \\
1.15\end{array}$ & $\begin{array}{l}1.15 \\
1.22^{*} \\
1.07 \\
1.03\end{array}$ \\
\hline $\begin{array}{l}\mathrm{KNO}_{3} \\
\quad 0.02 \mathrm{M}\end{array}$ & $1.97 *$ & 1.35 & 1.36 & $\underline{2.16^{* *}}$ & 0.89 & 1.10 & 1.12 \\
\hline $0.04 \mathrm{M}$ & 1.83 & $1.20^{* *}$ & 1.33 & $\overline{2.10} * *$ & 0.89 & 1.06 & 1.09 \\
\hline $0.08 \mathrm{M}$ & 1.73 & $1.20^{* *}$ & $1.14^{* *}$ & $1.75^{* *}$ & 0.85 & $\underline{0.94^{*}}$ & 0.94 \\
\hline $0.16 \mathrm{M}$ & $1.46^{* *}$ & $\overline{1.06 * *}$ & $0^{0.81^{* *}}$ & $1^{1.15^{* *}}$ & 0.71 & $\underline{0.71^{* *}}$ & 1.03 \\
\hline $\begin{array}{r}\mathrm{NH}_{4} \mathrm{NO}_{3} \\
0.02 \mathrm{M} \\
0.04 \mathrm{M}\end{array}$ & $\begin{array}{l}2.02^{* *} \\
1.80\end{array}$ & $\begin{array}{l}1.49 \\
1.44\end{array}$ & $\begin{array}{l}1.45 \\
1.45\end{array}$ & $\begin{array}{l}2.05^{* *} \\
1.81^{* *}\end{array}$ & $\begin{array}{l}0.97 \\
0.96\end{array}$ & $\begin{array}{l}1.00 \\
1.06\end{array}$ & $\begin{array}{l}1.16 \\
1.05\end{array}$ \\
\hline $0.08 \mathrm{M}$ & $1.93^{* *}$ & $\underline{1.31^{*}}$ & 1.35 & $1.66^{* *}$ & 0.91 & 1.05 & 1.11 \\
\hline $0.16 \mathrm{M}$ & $\underline{1.38 *}$ & $\overline{1.06}^{* *}$ & $0.92^{* *}$ & $\overline{0.84}$ ** & 0.76 & $\underline{0.74}^{* *}$ & 0.94 \\
\hline Heated seed & $3.08^{* *}$ & $2.59^{* *}$ & 1.59 & 2.36 & $1.38 * *$ & 1.05 & 1.04 \\
\hline
\end{tabular}

*Significant at 0.05 level; **significant at 0.01 level.

Underscored values indicate significant depression of rates at indicated levels of significance. 

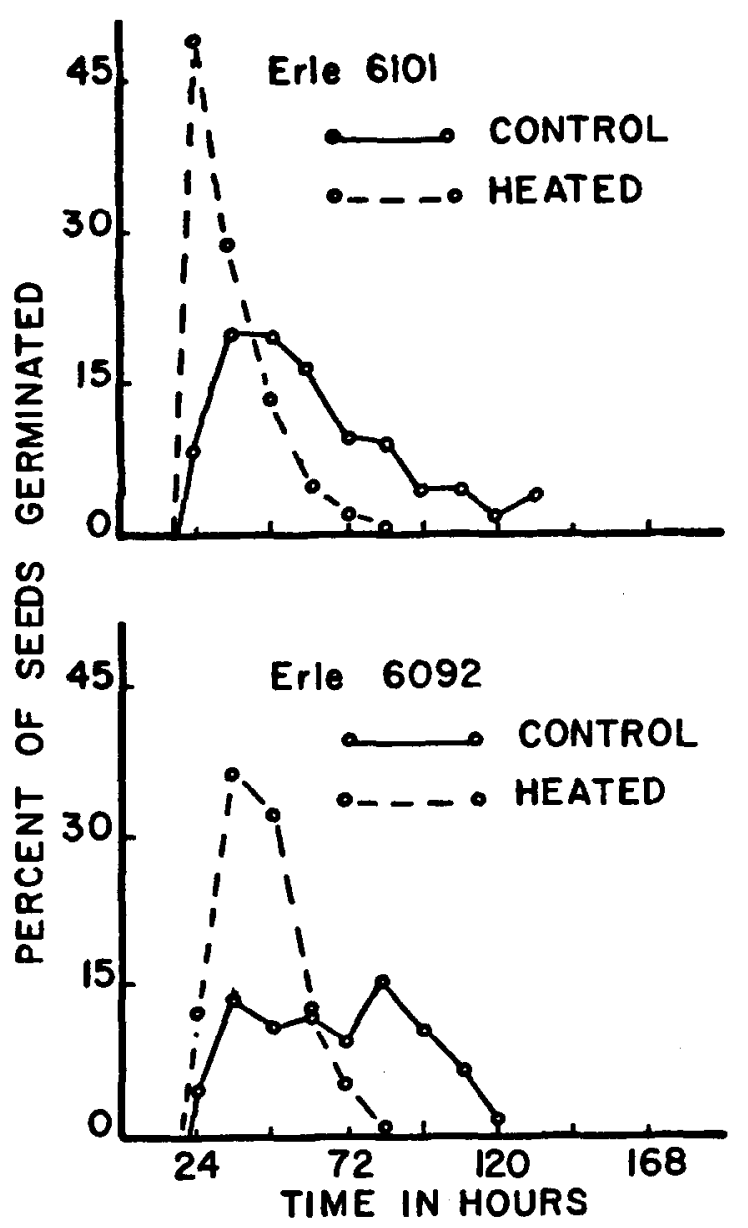

Fig. 1. Comparison of germination responses of heat-treated seed to nonireated control seed of 2 seed lots, 6101 and 6092, of Lehmann lovegrass. accession A-68.

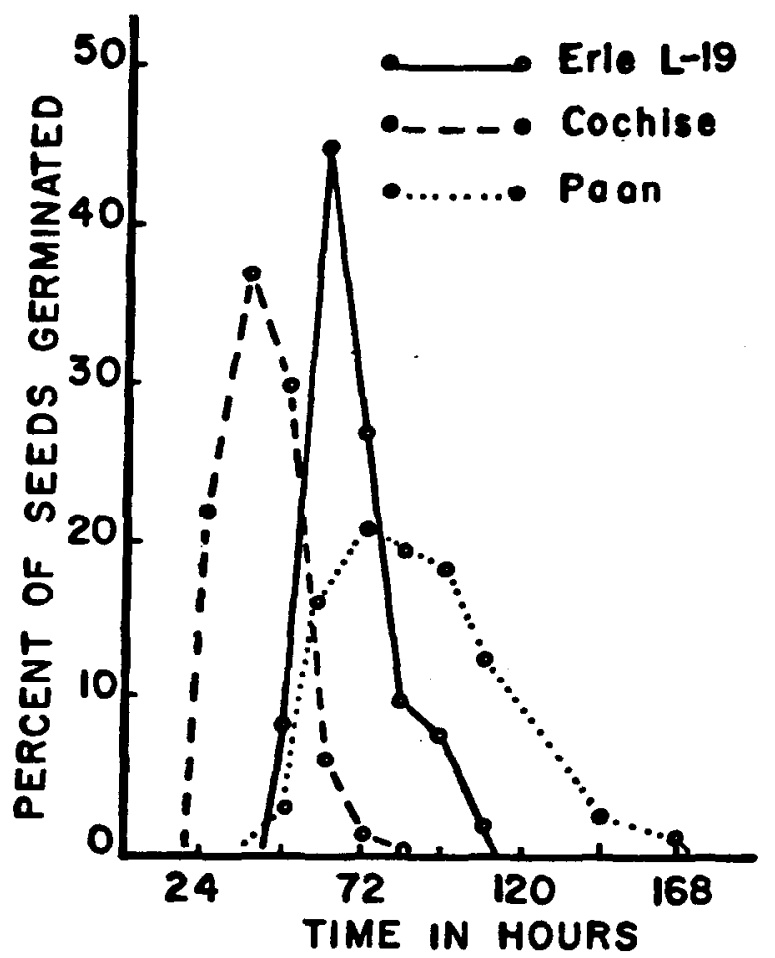

Fig. 2. Typical germination profiles from non-treated seed of Lehmann lovegrass, accession L-19, 'Cochise'lovegruss and blue panicgrass, accession $A-130$.

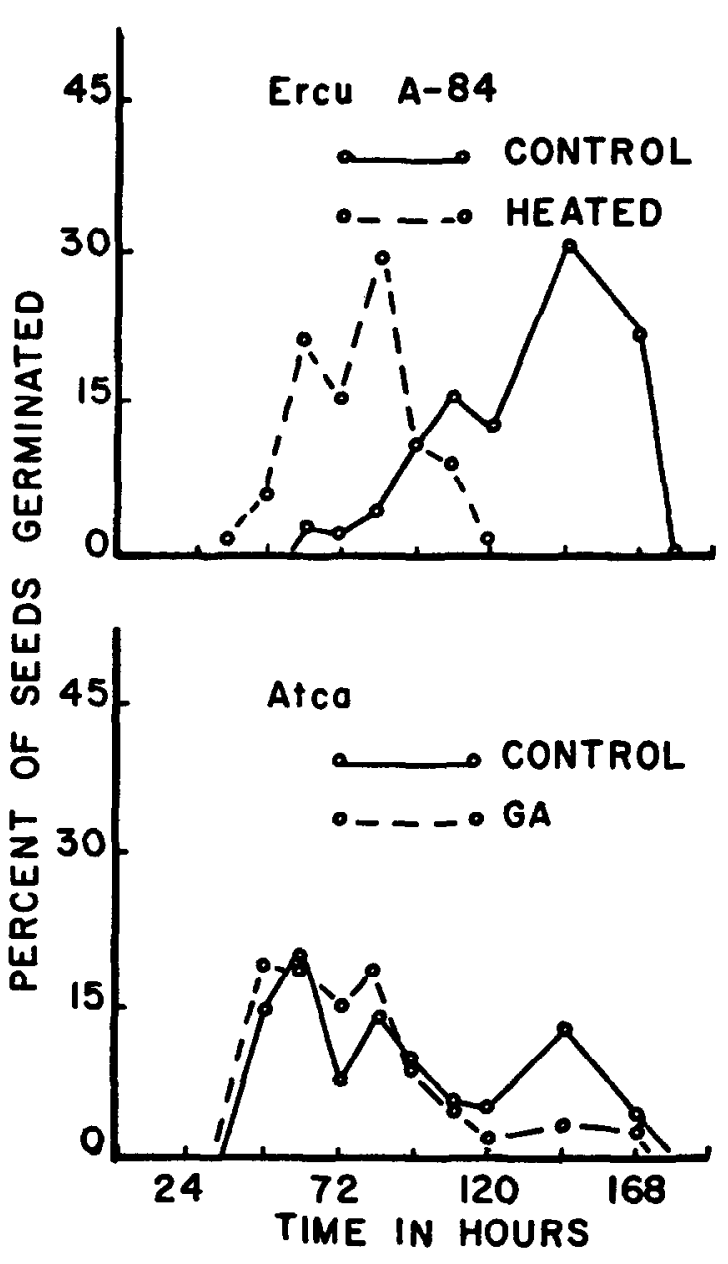

Fig. 3. Germination response of Boer lovegrass. accession A-84, to heattreated seed (above) and four-ning saltbush seed to $G A 0.14 \mathrm{mM}$, (below). Both are compared to non-treated control seed.

without effect including the depression of rates exhibited by other accessions at higher nitrate concentrations (Table 1, Fig. 3).

The only treatment affecting the germination rate of four-wing saltbush was GA at $0.14 \mathrm{mM}$, which gave an increase in rate (Table 1, Fig. 3).

The most important aspect of our study was that germination rates could be changed significantly by several factors, but different species or even different seed lots of the same species can be very specific in their response. Data indicated (Table 1) that treatments favorably increasing the germination rate of one seed lot may not be effective or may be inhibitory for another seed lot of the same accession or related accession. Lehmann lovegrass seed Lots 6092 and 6101 also varied in germination rates apparently due to different seasons of harvest. If subsequent research supports the premise that high germination rates aid in range seeding, seeds harvested under conditions which increase germination rates might qualify for premium prices. A standardized system of expressing germination rates of each seed lot, along with the pure, live seed index, would give additional information pertaining to the seed quality for range seeding.

Heat desiccation produced the greatest change in germination rates of Вoer lovegrass and Lots 6101 and 6092 of Lehmann lovegrass (Table 1). In fact, Lot 6092 responded favorably only to the heat treatment. In contrast to other treatments, there were no inhibitory effects from the heat treatment used on the accessions in this study. Development of methods and field plantings are needed to validate the use of heat-treated seeds for range seedings. 
Summer precipitation in Arizona is highly variable in distribution in time and amount. Sufficient soil moisture for germination is attained much more frequently, for example, for 40 -hour periods than for 100-hour periods. Wright and Streetman (1960) stated that grass species used for range seedings in the semiarid Southwest must be abie to establish rapidly in response to these short periods of intermittent moisture.

Ease of establishment of certain accessions in this study has been corroborated by Martin (1984). Listed in order of increasing mean time to germination, these accessions were 'Cochise' lovegrass, 42 hours; Lehmann lovegrass, 58 hours; blue panicgrass, 88 hours; and Boer lovegrass, 118 hours. It is suggested that germination rates be given greater consideration to support the suitability of plants selected for seeding specific range sites.

\section{Literature Cited}

Gulliver, R.L., and W. Heydecker. 1972. Establishment of seedlings in a changeable environment. p. 433-462. In: W. Heydecker (ed.) Seed Ecology. Penn State Univ. Park and London.

Gutterman, Y. 1972. Differences in the progeny due to daylength and hormone treatment of the mother plant. p. 59-80. In: W. Heydecker (ed.) Seed Ecology. Penn State Univ. Press, Univ. Park and London.

Haferkamp, M.R., and G.L. Jordan. 1977. The effect of selected presowing seed treatments on germination of Lehmann lovegrass seeds. J. Range Manage. 30:151-153.
Harrington, J.F. 1972. Problems of seed storage. p. 251-263. In: W. Heydecker (ed.) Seed Ecology. Penn State Univ. Press, Univ. Park and London.

Hartmann, H.T., and D.E. Kester. 1968. Plant propagation principles and practices. Prentice-Hall, Inc., Englewood Cliffs, New Jersey.

Jordan, G.L. 1981. Range seeding and brush management on Arizona rangelands. Coop. Ext. Ser., Agr. Exp. Sta. Bull. T81121. Univ. Arizona, Tucson, Arizona.

Koller, D. 1972. Environmental control of seed germination. p. 2-102. In: T.T. Kozlowski (ed.) Seed Biology. Vol. II. Germination Control, Metabolism, and Pathology. Academic Press, New York and London.

Lang, A. 1970. Gibberellins: structure and metabolism. Annu. Rev. Plant Physiol. 21:537-570.

Maguire, J.D. 1972. Physiological disorders in germinating seeds induced by the environment. p. 289-310. In: W. Heydecker (ed.) Seed Ecology. Penn State Univ. Press, Univ. Park and London.

Martin, M.H. 1984. Establishment of range grasses on various seedbeds at four (Larrea tridentata) sites in Chihuahua, Mexico and Arizona, U.S.A. M.S. Thesis, Univ. Arizona, Tucson.

Maun, M.A. 1977. Response of seeds to dry heat. Can. J. Plant Sci. 57:305-307.

Sosebee, R.E. 1977. Plant growth regulators. p. 185-215. In: R.E. Sosebee (ed.) Rangeland Plant Physiology. Society for Range Management. Denver, Colo.

Stone, E.C., and G. Juhren. 1951. The effect of fire on the germination of Rhus ovata. (Wats.) Amer. J. Bot. 38:368.

Wright, N., and L.J. Streetman. 1960. Grass improvement for the Southwest relative to drought evaluation. Arizona Agr. Exp. Sta. Tech. Bull. 143. Tucson, Arizona. 